\title{
ANALISIS KEWENANGAN CAMAT DALAM ERA OTONOMI DAERAH
}

\author{
Nabella \\ Magister Administrasi Publik, Fakultas Ilmu Sosial, Universitas Negeri Padang. \\ Email: nabella@student.unp.ac.id
}

\begin{abstract}
This study aimed to determine the authority of the Camat (Head of Subdistrict) in the Era of Local Autonomy in the District of Sitinjau Laut in Kerinci Regency and the effects that hamper the implementation of the authority of the Camat in Sitinjau Laut Regency, Kerinci Regency. This study is motivated by a number of problems including deterioration in the function, role and authority of the sub-district head in government and the sub-district head. It is still seen as an important institution and actor whose role is in fostering social relations and public services. This research is descriptive with a qualitative approach. Research informants determined intentionally. Data is collected by observing, interviewing, and studying the documentation and reducing it so that conclusions can be drawn. The results showed that the role of the sub-district head in the era of regional autonomy was said to be less effective and efficient because the subdistrict head only supervised the activities in the sub-district that had been made by the district head. in the midst of the community, and also the community expects the role of the sub-district to become a way for the community in government affairs which are considered to be more effective and efficient if the sub-district / sub-district government gets power in accordance with the conditions and conditions of the community in its area.
\end{abstract}

Keywords : Authority, service, regional autonomy

How to Cite: Nabella. 2019. Analisis Kewenangan Camat dalam Era otonomi Daerah. 3(2): pp.144-155. DOI: https://doi.org/10.24036/jess/vol3-iss2

\section{Pendahuluan}

Sejak kemerdekaan, Negara Indonosia menggunakan sistem negara kesatuan dengan bentuk pemerintahan presidensial.Negara kesatuan Republik Indonesia, menjalankan desentralisasi ke pemerintah daerah yang dilakukan dengan prinsip yaitu semua setiap kewenangan pemerintahaan pusat wajib berada di semua wilayah Negara Indonesia dan system Pemerintahannya.Kewenangan dan kepentingan pemerintahan pusat dilaksanakan sendiri atau diwakilkan kepada semua jenjang struktur pemerintahan dari pusat ke daerah.Pentingnya peranan dan kewenangan pemerintahan pusat yang tidak mampu dihapuskan dan dibatasi, tetapi terjadi sampai jenjang tatanan pemerintahan dan tingkat hierarki yang khusus, Andi (2013). 
Kecamatan merupakan bagian wilayah administratif di Indonesia di bawah kabupaten atau kota. Kecamatan terdiri atas desa-desa atau kelurahan-kelurahan. Kecamatan atau sebutan lain adalah wilayah kerja camat sebagai perangkat daerah kabupaten/kota. Kedudukan kecamatan merupakan perangkat daerah kabupaten /kota sebagai pelaksana teknis kewilayahan yang mempunyai wilayah kerja tertentu dan dipimpin oleh camat. Dalam konteks otonomi daerah di Indonesia, Kecamatan merupakan Satuan Kerja Perangkat Daerah (SKPD) Kabupaten atau Kota yang mempunyai wilayah kerja tertentu yang dipimpin oleh Camat, Hanif (2005).

Pengaturan penyelenggaraan kecamatan seperti pembentukan, kedudukan, tugas dan fungsinya secara legalistik diatur dengan Peraturan Pemerintah.Sebagai perangkat daerah, Camat mendapatkan pelimpahan kewenangan yang bermakna urusan pelayanan masyarakat. Selain itu kecamatan juga akan mengembang penyelenggaraan tugas-tugas umum pemerintahan. Perjalanan organisasi kecamatan tidak dapat dipisahkan dari asas pemerintahan yang digunakan, yaitu asas desentralisasi dan asas dekonsentrasi.Penerapan asas desentralisasi secara penuh di tingkat kabupaten/kota berdampak pada wewenang, status, peran dan fungsi camat. Namun demikian, kebijakan desentralisasi pemerintahan untuk mewujudkan otonomi daerah sedang menjadi kepedulian tinggi sesuai dengan laju reformasi, yang bertujuan memeratakan kesejahteraan dan tanggung jawab daerah dalam pembangunan bangsa, Iskandar (2013).

Dinamika kewenangan camat sejak diberlakukannya UU Nomor 23 tahun 2014 tentang Pemerintah daerah, memang telah membawa dampak pada perubahan kewenangan camat (menyempitnya kewenangan camat) sebagai kepala pemerintahan kecamatan. Sudah semestinya undang-undang tersebut semakin mempertajam kewenangan camat dalam era otonomi daerah di kecamatan demi menciptakan masyarakat yang mandiri dan madani. Kewenangan camat seharusnya disesuaikan dengan kebutuhan masyarakat lokal, agar institusi kecamatan dan camat dapat dengan maksimal memberikan pelayanan yang diharapkan masyarakat lokal. Dalam hal ini bupati/wali kota sudah selayaknya melakukan pendelegasian wewenang secara demokratis dan berkesinambungan kepada kecamatan dan camat demi menjalankan political will yang positif sesuai amanat Pasal 225 UU No. 23 Tahun 2014, dan tidak terjadinya penumpukan kekuasaan serta eksistensi kecamatan dan camat dapat kembali hidup sesuai dengan keinginan masyarakat lokal pada umumnya, Yusdianto (2015).

Kecamatan Sitinjau Laut adalah kecamatan yang telah mengalami kemajuan dan pertumbuhan di berbagai aspek, bila kita lihat dan kita sandingkan kecematan sitinjau laut dan kecematan lain di Kabupaten Kerinci. Kecamatan Sitinjua Lautsecara keseluruhan merupakan masyarakat yang bercorak di sketor pertanian, yang merupakan sistem ketahanan pangan masyarakat Kecamatan Sitinjau Laut, dan ada juga sebagian masyarakat berkebun, berternak dan lain 
sebagainya yang menjadi sistem ketahanan kehidupan masyarakat kecamatan sitinjau laut dalam Sumber Daya Alam (SDA), Kecamatan Sitinjau Laut saat ini sudah bisa dikatakan kecamatan yang berpotensi dalam aspek atau sistem otonomi daerah.

Sejalan dengan kemorosotan fungsi, peran dan kewenangan camat dalam pemerintahan, masyarakat sitinjau laut ternyata memiliki pandangan yang boleh berbeda. Bagi masyarakat yang ada di desa atau masyarakat pada umumnya, kecamatan dan camat ternyata tetap dipandang sebagai institusi dan aktor penting yang peranannya dalam pembinaan hubungan sosial kemasyarakatan dan pelayanan publik secara realistis belum bisa digantikan oleh institusi atau mekanisme lain. Fakta yang terungkap dilapangan menyebutkan bahwa masyarakat lokal sama sekali tidak menghendaki penghapusan kecamatan dalam sistem tata pemerintahan daerah. Artinya kecamatan dan camat tetap dipandang sebagai institusi yang memiliki nilai lebih dalam kehidupan sosial kemasyarakatan lokal.

Untuk mempermudah pemahaman dalam penelitian ini, penulis menggunakan kerangka pemikiran dari Koontz, O'Donnell and Weihrich yang dikutip oleh Wasistiono (2009) yaitu; Indikator pertama Hasil yang dapat diperkirakan yaitu pelimpahan yang diberikann berlandaskan arah dan konsep yang sudah disiapkan sebelumnya, Kedua Prinsip defenisi fungsional yaitu pelimpahan kewenangan harusnya dilandaskan pertimbangan-pertimbangan fungsional supaya tugas atau kewajiban tertentu dapat dikerjakan secara lebih efektif dan efesien, Ketiga Kejelasan hierarki jabatan terhadap kewenangan yaitu pelimpahan kewenangan secara beratuturan atau berurutan dari jabatan tertinggi hingga jabatan terendah, Keempat Jenjang kewenangan yaitu adanya pelimpahan secara bertahap berlandaskan tingkat kewenangan yang dimiliki pemimpin atau satu unit organisasi tertentu, Kelima Kesatuan komando yaitu mengharuskan akan pentingnya satu kesatuan komando dalam pelimpahan kewenangan, Keenam Tanggung jawab yang penuh/jelas yaitu pelimpahan kewenangan disertai dengan pemberian penuh tanggung jawab berate Cuma kepada pihak-puhak yang diberikan delegasi kewenangan, Ketujuh Keseimbangan kewenanganyaitu kewenangan yang diberikanwajib dibarengi tanggung jawab yang seimbang.

Berdasarkan latar belakang di atas, maka dapat dirumuskan yang menjadi pokok permasalahan dalam penulisan ini adalah bagaimanakah kewenangan Camat dalam Era Otonomi Daerah pada Kecamatan Sitinjau Laut Kabupaten Kerinci.

\section{Tinjauan Kepustakaan}

Syafrudin (2000) menurutnya kewenangan dan wewenang, harus dibedakan keduanya yaitu kewenangan (authority, gezag) dengan wewenang (competence, bevoegheid). Kewenangan yaitu biasa disebut dengan kekuasaan formal 
maksudnya adalah kekuasaan yang berpedomandari kekuasaan yang diberikan oleh undang-undang. Wewenang yaitu mengenai suatu "onderdeel" (bagian) tertentu saja dari kewenangan. Di dalam kewenangan terdapat wewenangwewenang (rechtsbe voegdheden). Wewenang adalah bagian dari hukum publik, bagian dari wewenang pemerintahan, tidak hanya wewenang untuk membuat keputusan pemerintah (bestuur), tetapi meliputi wewenang adalah pelaksanaan kewajiban dan memberikan wewenang serta pembagian wewenang sudah ditetapkan dalam peraturan perundang-undangan.

Menuru Zaini (2017) Pendelegasian merupakan alokasi atau pembebanan tugas, wewenang dan permintaan akan pertanggungjawaban pelaksanaan tugas. Pendelegasian harus jelas kepada posisi tertentu, siapa orang yang akan menempati posisi tersebut dan bagaimana pelaksanaannya. Tentu saja perlu keluwesan tertentu agar supaya pelaksanaan tugas berjalan sebagaimana mestinya.Beberapa prinsip pendelegasian perlu dianut: Pertama, Prinsip defenisi fungsi, yaitu bahwa isi setiap posisi atau kedudukan haruslah dibatasi dengan jelas sedangkan hubungan wewenang perlu digariskan semacam deskripsi jabatan; Kedua, Prinsip skalar, yaitu kebalikan akan adanya rantai hubungan wewenang langsung atasan bawahan secara menyeluruh; bawahan harus tahu siapa atasannya; Ketiga, Prinsip tingkat wewenang, yang menyatakan bahwa wewenang mengambil keputusan yang tidak dapat dilakukan pada suatu tingkat hendaknya dilakukan oleh atasan; Keempat, Prinsip delegasi berdasarkan hasil yang diharapkan memberikan kejelasan pada bawahan seberapa jauh dia harus bertindak; Kelima, Prinsip kemutlakan tanggungjawab, berarti bahwa tanggung jawab bawahan pada atasannya itu mutlak; sebaliknya atasan tak dapat menghindari tanggung jawab walaupun dia telah mendelegasikan wewenangnya; KeenamPrinsip paritas antara wewenang dan tanggung jawab, yang berarti bahwa manajer di dalam menjalankan wewenangnya juga harus bertanggung jawab sama terhadap hasil-hasilnya; Ketjuh, Prinsip kesatuan perintah, berarti bawahan harus melapor pada satu atasan saja kecuali dalam hal-hal seperti wewenang bersama dipecah antara atasan dan bawahan.

Menurut Pasal 225 dan 226 UU No. 23 Tahun 2014 tentang Pemerintah daerah dan Peraturan Bupati (PERBUP) tentang Pelimpahan kewenangan Bupati Kerinci kepada Camat untuk melaksanakan urusan pemerintah daerah, disebutkan bahwa: Tugas Camat diatur pada Pasal 225 UU No 23 Tahun 2014: Dalam ayat 1 pasal 225 dijelaskan bahwa Penyelenggaraan kegiatan pemerintah umum sebagaimana yang dikatakan pada Pasal 25 ayat 6 yang berbunyi; Mengawasi dan mengarahkan aktivitas dalam pemberdayaan masyarakat; Mengawasi dan mengarahkan dalam upaya penyelenggaraan ketenteraman dan ketertiban umum; Mengawasi dan mengarahkan pelaksanaan dan penegakan Perda dan Perkada; Mengawasi dan mengarahkan pemeliharaan prasarana dan sarana pelayanan publik; Mengawasi dan mengarahkan penyelenggaraan aktivitas pemerintah 
dilakukan oleh Perangkat Daerah di Kecamatan; Membina dan mengawasi penyelenggaraan kegiatan Desa atau kelurahan; Menjalankan Urusan Pemerintahan yang menjadikan kewenangan Daerah kabupaten/kota tidak dilaksanakan oleh unit kerja Perangkat Daerah di kabupaten/kota yang ada di Kecamatan; dan Menjalankan aktivitas yang sesuai dalam ketentuan peraturan undang-undang.

Pada pasal 225 dijelaskan bahwa Camat melakukan tugasnya yang berbunyi pada ayat (1) camat yang diperbantu pegawai Kecamatan. Dan juga Camat diberi pelimpahan wewenang, yang telah diatur pada Pasal 226 UU No. 23 Tahun 2014 yang berbunyi, Selain melakukan kewajiban yang dimaksud Pasal 225 ayat 1 , camat diberikan pelimpahan beberapa kewenangan dari bupati/wali kota dalam melaksanakan sebagian Urusan Pemerintah yang menjadi kewenangan Daerah kabupaten/kota; Pelimpahan kewenangan bupati/wali kota pada ayat (1) dilakukan berdasarkan penataan dalam pelayanan publik yang sama dengan karakteristik Kecamatan dan keperluan masyarakat di Kecamatan yang dimaksud; Pelimpahan kewenangan bupati/wali kota pada ayat (2) telah menguatkan dalam keputusan bupati/wali kota yang berpedoman pada aturan pemerintahan.

Pelimpahan kewenangan Bupati Kerinci untuk Camat untuk melaksanakan urusan pemerintah daerah telah ditetapkan dalam Peraturan Bupati Nomor 23 Tahun 2014 Pasal 2 Tentang Tugas dan kewenangan Camat. Camat menyelenggarakan tugas umum pemerintahan yang meliputi Mengkoordinasikan kegiatan pemberdayaan masyarakat; Mengkoordinasikan upaya penyelenggaraan ketentraman dan ketertiban umum; Mengkoordinasikan penerapan dan penegakan peraturan undang-undangan; Mengkoordinasikan pemeliharaan prasarana dan fasilitas umum; Mengkoordinasikan penyelenggaraan kegiatan pemerintahan ditingkat kecamatan; Membina penyelenggaran pemerintahan desa atau kelurahan; Melaksanakan pelayanan masyarakat yang menjadi ruang lingkup tugasnya atau yang belum dilaksanakan pemerintahan desa atau kelurahan.

Pasal 226 ayat 1 UU No 23 Tahun 2014 Tentang Pemerintah Daerah, yaitu camat mendapatkan pelimpahan sebagian kewenangan bupati/wali kota untuk melaksanakan sebagian Urusan Pemerintahan yang menjadi kewenangan Daerah kabupaten/kota. Perubahan kedudukan kecamatan sebagai perangkat daerah, berimplikasi terhadap kewenangan yang mendasari pelaksanaan tugas-tugasnya memiliki kesamaan dengan perangkat daerah lainnya. Bahwa, tugas-tugas yang dilaksanakan setiap perangkat daerah berdasarkan kewenangan yang didelegasikan, namun untuk kecamatan tugasnya cenderung lebih bersifat umum berkaitan dengan kewenangan atributif dan menyangkut berbagai aspek dalam pemerintahan dan pembangunan. Hal ini berbeda dengan perangkat daerah lainnya (dinas/lembaga teknis) yang lebih bersifat spesifik. Oleh karenanya, untuk menghindari terjadinya overlapping dalam penyelenggaraan tugas, maka sangat diperlukan kejelasan mengenai kewenangan delegatif kecamatan. 
Pada masa berlakunya UU Nomor 5 Tahun 1974, camat merupakan kepala wilayah. Pada pasal 76 dinyatakan setiap wilayah dipimpin oleh seorang kepala wilayah. Dalam pasal 77 dinyatakan bahwakepala wilayah kecamatan disebut camat. Dalam pasal 80 dinyatakan kepala wilayah sebagai wakil pemerintah adalah penguasa tunggal di bidang pemerintahan dalam wilayahnya dalam arti memimpin pemerintahan mengoordinasikan pembangunan dan membina kehidupan masyarakat di segala bidang. Wewenang, tugas, dan kewajiban camat selaku kepalawilayah kecamatan sama dengan wewenang, tugas,dan kewajiban kepala wilayah lainnya, yakni gubernur,bupati, dan walikota.

Dari sini terlihat betapa kuatnya posisi dan kewenangan seorang camat di wilayah kecamatan. Camat adalah kepala wilayah, wakil pemerintah pusat, dan penguasa tunggal di wilayah kecamatan yang dapat mengambil segala tindakan yang dianggap perlu untuk menjamin kelancaran penyelenggaraan pemerintah. Meskipun camat adalah bawahan bupati/walikota, camat mempunyai kewenangan yang cukup besar di wilayahnya. Tidak heran pada masa UU Nomor 5 Tahun 1974, camat dapat memutuskan segala sesuatu tanpa perlu mengkonsultasikannya dengan bupati. Pada masa ini telah berlakunya UU No 23 Tahun 2014, camat tidak lagi menjadi kepala wilayah, melainkan sebagai perangkat daerah. Seperti telah disebutkan sebelumnya, dinyatakan bahwa perangkat daerah kabupaten/kota terdiri atas sekretariat daerah, sekretariat DPRD, inspektorat, dinas daerah, lembaga teknis daerah, kecamatan.Jadi, secara hukum posisi camat sejajar dengan posisi para kepala dinas daerah.

\section{Metode Penelitian}

Penelitian menggunakan pendekatan kualitatif dengan metode deskriptif. Fokus penelitian yaitu pada Analisis Kewenangan Camat dalam Era Otonomi Daerah pada Kecamatan Sitinjau Laut Kabupaten Kerinci.Waktu penelitian selama 3 bulan dari bulan Mei sampai dengan buluan juli 2018.Tempat Penelitian ini dilakukan di Kantor Camat Sitinjau Laut dan Masyarakat Kecamatan Sitinjau Laut Kabupten Kerinci Provinsi Jambi. Untuk pemilihan informan dalam penelitian ini dilakukan secara sengaja (purposive). Data penelitian diperoleh langsung dari informan yaitu Indri Firman Camat Sitinjau Laut, Harpan Feri selaku Sekretaris Camat Sitinjau Laut, Tablik Depati Kasi Pemerintahan Sitinjau Laut, Nova Oktavia Kasi Ketentraman dan Ketertiban Sitinjau Laut, Amarudiin Kasi Ekonomi dan Pembangunan Sitinjau Laut, Indrawati Kasi Kesejahteraan Sosial dan Pelayanan Umum, Saipul Amri Kasi Aset dan Keuangan Desa Sitinjau Laut dan Buswaria Tokoh Masyarakat.

Teknik pengumpulan data yang penulis gunakan dalam penelitian adalah teknik observasi, wawancara, dan studi dokumentasi. Dalam mengumpulkan datadata penulis menggunakan instrument penelitian yaituLaptop, Tipe 
Recorder/Handphone, Pena dan Buku. Teknik analisis data yang digunakan adalah reduksi data, penyajian data, dan penarikan kesimpulan, Sugiyono (2012).

\section{Hasil dan Pembahasan}

\section{Hasil Penelitian}

Berdasarkan hasil penelitian yang dilakukan di Kantor Camat Sitinjau Laut yaitu : Pertamahasil yang dapat diperkirakan, hasil penelitian yaitu rencana dan kebijakannya haruslah jelas dan terarah. Meskipun eksistensi lembaga kecamatan kurang dirasakan oleh masyarakat, namun hal ini tidak dapat menjadi tolak ukur masyarakat dalam menilai kinerja kecamatan, karena kewenangan camat dalam hasil yang dapat diperkirakan, saat ini telah berjalan dengan sangat baik, hal ini dibuktikan dengan tidak adanya kegiatan/pekerjaan yang tidak selesai tepat pada waktunya dan pelaksanaan kegiatan/pekerjaan pada masing-masing bidang di pemerintahan kecamatan berjalan sangat baik karena ditangani oleh orang-orang yang berpengalaman dibidangnya masing-masing.

Kedua Defenisi Fungsional, hasil penelitian yaitu agar tidak lagi ada masyarakat yang mengeluh tentang permasalahan-permasalahan administrartif, di dalam setiap pekerjaan dan kegiatan yang dilakukan harus mempunyai target dan sasaran, dan saat ini lebih efisien dan efektif karena sesuai target dan sesuai yang diharapkan. Maksud dari target sasaran itu harus sesuai dengan kondisi ditengah masyarakat, apa yang dibutuhkan masyaraka di wilayah tersebut dan apa-apa program yang telah dan ingin dilaksanakan sesuai dengan harapan dan kondisi di daerah setempat, selain itu pertimbangan-pertimbangan tentang efektifitas dan efisiensi suatu kegiatan/pekerjaan juga menjadi alasan yang kuat dalam prinsip ini dan telah dilaksanakan sesuai dengan aturan-aturan yang ada.

Ketiga kejelasan hierarki jabatan, Berdasarkan Indikator dan hasil penelitian yaitubahwa kewenangan camat dalam kejelasan hierarki jabatan belum dirincikan dengan baik, mekanisme yang dibangun di kecamatan pun memunculkan celah-celah untuk memainkan kepentingan politik individu/sekelompok orang yang berkuasa.

Keempat Jenjang Kewenangan, Berdasarkan indikator dan menurut analisa peneliti bahwa kewenangan camat dalam jenjang kewenangan tidak serta merta ditunjang dengan pertimbangan bidang keahlian ataupun pengalaman kerja dalam menetapkan urutan penempatan jenjang kewenangan tersebut dikarenakan camat lah yang mempunyai kuasa untuk melimpahkan sebagian kewenangannya dalam situasi tertentu berdasarkan pertimbangan-pertimbangannya sendiri, dan jenjang kewenangan yang telah dijalankan di kecamatan sudah tepat tinggal ditingkatkan dengan menempatkan pelimpahan kewenangan berdasarkan keahlian masing-masing individu di lembaga kecamatan, bukan hanya didasari unsur politis saja, melainkan harus mempertimbangkan kefektifan dalam penempatan suatu kewenangan pada orang-orang yang sesuai dengan kapasitas mereka 
masing-masing agar kewenangan yang dijalankan dapat dipertanggung jawabkan dikemudian hari.

Kelima Kesatuan Komando, Berdasarkan indikator dan menurut analisa peneliti bahwa kewenangan camat dalam kesatuan komando hanya sebatas koordinasi dan fasilitasi dalam hubungannya dengan instansi yang ada di kecamatan ataupun organisasi kemasyarakatan yang ada di kecamatan. Walaupun pertanggung jawaban camat secara administratif melalui sekretaris daerah, namun secara struktural camat berada langsung dibawah bupati/wali kota, bahwa kesatuan komando terlihat dari Peraturan bupati No.23 tahun 2014 mengenai Kecamatan, dimana camat dalam menjalankan tugasnya dibantu oleh perangkat kecamatan dan bertanggung jawab kepada bupati/wali kota melalui sekretaris daerah kabupaten/kota.

Keenam Tanggung Jawab yang Penuh/Jelas, berdasarkan indikator dan menurut analisa peneliti kewenangan camat dalam tanggung jawab yang jelas/penuh mengharapkan pelimpahan kewenangan yang disesuaikan dengan kondisi masyarakat lokal atau dengan kata lain lembaga kecamatan akan lebih efektif dan efisien apabila dilimpahkan kewenangan yang penuh/jelas dalam penyelenggaraan pemerintahan, kewenangan camat dalam tanggung jawab yang penuh dan jelas sebenarnya sangat berharap adanyan keiinginan politik (political will) dengan Bupati dan DPRD dalam membuat kecamatan sebagai pelayanan utama masyarakat, apapun program. yang dilaksanakan dikantor camat tanggung jawabnya adalah pimpinan (camat).

Ketujuh Keseimbangan Kewenangan, Berdasarkan indikator dan menurut analisa peneliti kewenangan camat dalam keseimbangan kewenangan menuntutcamat untuk arif, kretif, berinovasi dan proaktif dalam memberi masukan kepada kepala daerah agar kepala daerah memahami dan memberikan kekuasaan yang dibutuhkan lembaga kecamatan dalam penyelenggaraan pemerintahan, kewenangan camat dalam keseimbangan kewenangan berjalan dengan baik dan sesuai dengan apa yang menjadi harapan lembaga kecamatan saat ini, dimana hal ini tercermin dalam pertanggung jawaban yang langsung kepada kepala daerah dengan menyerahkan hasil kepada pemerintah di tingkat kecamatan kepada kepala daerah melalui sekretaris daerah, harapan lembaga untuk meningkatkan pelayanan terhadap masyarakat lebih baik, meiningkatkan pembinaan pelayan, pemberdayaan masyarakat dan penyelenggaraan pemerintah desa, serta Meningkatkan pembinaan dan fasilitas pembangunan wilayah kecamatan.

\section{Pembahasan}

Berdasarkan hasil penelitian yang dilakukan di Kantor Camat Sitinjau Laut yaitu : Pertama hasil yang dapat diperkirakan menurut analisa peneliti bahwa kewenangan camat dalam hasil yang dapat diperkirakan berjalan dengan baik 
sesuai dengan teori oleh Koontz, O’Donnell dan Weihrich yang dikutip oleh Wasistiono (2009) yang menyatakan bahwa pelimpahan diberikan berdasarkan tujuan dan rencana yang telah disiapkan sebelumnya.

Kedua Defenisi Fungsional, Ini sesuai dengan ungkapan Koontz, O’Donnell dan Weihrich yang telah dikutip Wasistiono (2009) yang menyatakan dengan adanya pelimpahan kewenangan telah berlandaskan berdasarkan jabatan sehingga kewajiban dapat dilaksanakan dengan baik.

Ketiga kejelasan hierarki jabatan, Hal ini tidak sesuai dengan teori yang dikemukakan oleh Koontz, O’Donnell dan Weihrich yang dikutip oleh Wasistiono (2009) yang menyatakan bahwa pengharapan pelimpahan dengan cara berlahanlahan dengan dasar jenjang kewenangan yang telah dimiliki oleh pemimpin dan organisasi tertentu, karena dalam mekanisme yang dibangun di kecamatan yang berkaitan dengan kejelasan hierarki jabatan memunculkan celah-celah untuk memainkan kepentingan politik individu/sekelompok orang.

Keempat Jenjang Kewenangan, Hal ini sesuai dengan teori yang dikemukakan oleh Koontz, O'Donnell danWeihrich yang dikutip oleh Wasistiono (2009) yang menyatakan bahwa prinsip ini menginginkansebuah pelimpahan secara perlahan-lahan berdasarkan jenjang kewenangan yang dimiliki oleh pemimpindan organisasi tertentu.

Kelima Kesatuan Komando,hal ini sesuai dengan teori yang dikemukakan oleh Koontz, O’Donnell dan Weihrich telah dikutip Wasistiono (2009) yang menyatakan bahwa prinsip ini menekankan akan pentingnya satu kesatuan komando dalam pelimpahan kewenangan.

Keenam Tanggung Jawab yang Penuh/Jelas, Hal ini sesuai dengan teori yang dikemukakan oleh Koontz, O’Donnell dan Weihrich yang dikutip oleh Wasistiono (2009) yang menyatakan bahwa menginginkan pemberian kewenangan adil dalam pelimpahan penuh tanggung jawabdengan pihak yang diberikan delegasi kewenangan, kemudian pihak yang memberikan tidak ikut serta dalam urusan yang telah diberikan.

Ketujuh Keseimbangan Kewenangan, Hal ini sesuai dengan teori yang dikemukakan Koontz, O'Donnell dan Weihrich yang dikutip oleh Wasistiono (2009) yang menyatakan dengan kewenangan yang telah diberikan wajib disertai tanggungjawab.

Kewenangan camat dalam era otonomi daerah di Kecamatan Sitinjau Laut Kabupaten Kerinci, Perubahan yang terjadi dalam pengelolaan pemerintahan kecamatan sudah dicantumkan di UU No 22 Tahun 1999, setelah itu pada UU No23 Tahun 2014. Perubahan ini tentang posisi kecamatan yang telah menjadi salah satu perangkat daerah kabupaten/kota, dan camat menjadi pemimpin pemerintahan yang menjalani wewenang bupati/walikota. Dalam Pasal 209 ayat 2 UU Nomor 23 Tahun 2014 yang berbunyi "Perangkat daerah kabupaten/kota yaitu sekretariat daerah, sekretariat DPRD, inspektorat, dinas daerah, lembaga teknis 
daerah, kecamatan". Pasal diatas menyebutkan ada perubahan yang harus diketahui mengenai Kecamatan tidak lagi area administrasi pemerintahan dan merupakan wilayah kekuasaan camat. Dengan perubahan baru yaitu, kecamatan adalah area tugas atau areacamat untuk bertugas; Camat merupakan perangkat daerah kabupaten/kota dan tidak lagi menjadi kepala area administrasi pemerintah kecamatan jadi camat tidak lagi menjadi pemimpin kecamatan yang mengatur kecamatan sebagai administrator pemerintahan, pembangunan dan kemasyarakatan, tetapi camat sekarang sebagai pelaksana sebagian wewenang yang telah diberikan bupati/walikota.

Hasil penelitian menunjukkan bahwa Perubahan paradigm penyelanggaraan pemerintahan daerah tersebut, mengakibatkan pola distribusi kewenangan Camat menjadi sangat tergantung pada pendeglegasian sebagian kewengan pemerintahan dari bupati untuk menangani sebagian urusan otonomi daerah dan penyelenggara pemerintahan umum, yang mempunyai implikasi langsung terhadap optimalisasi peran kerja dan kinerja Camat dalam upaya pemenuhan pelayanan kepada masyarakat. Dalam Undang-undang Nomor 23 tahun 2004 tentang Pemerintahan Daerah. Sejalan dengan itu camat tidak lagi ditempatkan sebagai Kepala Wilayah dan wakil Pemerintahan Pusat seperti yang terdapat dalam Undang-Undang Nomor 5 tahun 1974. Dapat dikatakan bahwa posisi camat tetap ada di kecamatan tetapi tergantung pada kewenangan delegatif yang diberikan, yang terjadi di Kecamatan Sitinjau Laut bukan secara legal formal kewenangan delegatif yaitu seperti yang terjadi dalam artian anggapan (penerimaan) yang sudah dirancang. Peran camat seperti mengkoordinasikan, membina, dan mengawasi semua bentuk penyelenggaraan pemerintahan di wilayahnya termasuk juga penyelenggaraan pemerintah desa. Jadi dapat kita lihat, Camat Sitinjau Laut dalam menyelenggarakan sebagaian urusan pemerintah daerah hampir tidak terlihat.Kewenangan yang dijalankan hanyalah kewenangan rutinitas biasa, akibat anggapan yang telah dirancang oleh masyarakat dan pemerintah daerah Kabupaten Kerinci dalam hal ini ialah Bupati Kerinci.

Harapan penulis dalam kewenangan camat pada era otonomi daerah yaitu Pada saat ini tugas umum pemerintahan yang diselenggarakan oleh camat hanya mencakup tiga jenis kewenangan, yaitu kewenangan melakukan kordinasi yang meliputi lima bidang kegiatan, kewenangan melakukan pembinaan dan kewenangan melaksanakan pelayanan kepada masyarakat. Hal ini disebabkan camat tidak lagi berperan sebagai kepala wilayah. Menyadari kedudukan camat yang strategis itu, yang perlu dilakukan oleh pemerintah daerah bupati/walikota seharusnya menjadikan camat sebagai bagian dari pemerintah daerah dalam menyelenggarakan otonomi daerah. Selain itu, bupati atau walikota perlu memberikan penguatan peran camat, melalui pelimpahan urusan pemerintahan yang menjadi kewenangan daerah (bupati atau walikota), termasuk penanganan konflik sosial. 
Hal ini sesuai dengan hasil penelitian Muhammad Ade (2011) dijelaskan bahwa pelaksanaan tugas dan fungsi camat dalam penyelenggaraan pemerintahan di Kecamatan Pallangga Kabupaten Kabupaten Gowa meliputi pengarahan, pembinaan, pengawasan dan evaluasi telah di laksanakan oleh camat Pallangga sesuai dengan ketentuan undang-undang Nomor 23 Tahun 2014. Dari hasil penelitian dan hasil penelitian terdahulu dapat disimpulkan bahwa fungsi kewenangan pada kecamatan Sitinjau Laut ini adalah Mengoordinasikan kegiatan pemberdayaan masyarakat, Mengoordinasikan upaya penyelenggaraan ketenteraman dan ketertiban umum, Mengoordinasikan penyelenggaraan kegiatan pemerintahan di tingkat kecamatan, Membina penyelenggaraan pemerintahan desa, dan Melaksanakan pelayanan masyarakat yang menjadi ruang lingkup tugasnya, jadi fungsi kewenangan camat di era otonomi daerah hanya mengkoordinasi bukan lagi sebagai kepala wilayah pemerintahan kecamatan.

\section{Kesimpulan}

Peletakkan kembali kewenangan camat dalam era otonomi daerah membuka ruang untuk camat/institusi kecamatan agar dapat kembali eksis ditengah-tengah masyarakat yang sangat mengharapkan peran kecamatan menjadi satu-satunya jalan bagi masyarakat dalam urusan-urusan pemerintahan yang dinilai masyarakat lokal lebih efektif dan efisien apabila camat/institusi kecamatan mendapatkan kekuasaan yang sesuai dengan keadaan dan kondisi masyarakat di wilayahnya. Kepala Daerah Kabupaten Kerinci meminta dan berharap kecamatan merupakan pusat pemerintahan kecamatan pemerintah daerah yang menjadikan tempat pelayanan tapi di suatu sisi tidak adanya pendelegasian wewenang dengan rinci mengakibatkan camat seringragu-ragu dan bingung dalam menjalankan tugasnya.

\section{DAFTAR KEPUSTAKAAN}

Andi Muhammad Ade F. "Analisis Peran Camat dalam Penyelenggaraan Pemerintahan di Kecamatan Pallangga Kabupaten Gowa”. Jurnal Ilmu Pemerintahan. Volume 6, Nomor 2, Juli 2013, (89-100) ISSN 1979-5645.

Hanif Nurcholis, 2005. "Teori dan Praktek Pemerintahan dan Otonomi Daerah". Grasindo, Jakarta.

H.R Syaukani dkk, 2002, Otonomi Daerah dalam Negara Kesatuan, Pusat Pengkajian Etika Politik dan Pemerintahan, Yogyakarta.

Irfan Fachruddin, Stout HD, De Betekenissen Van De Wet, 2004, "Pengawasan Peradilan Administrasi terhadap Tindakan Pemerintah". Alumni,

Iskandar Mardani. "Pelimpahan Kewenangan Bupati Dalam Otonomi Daerah (Kajian Pelimpahan Kewenangan Delegatif Bupati Kepada Camat Di Kabupaten Parigi Moutong Propinsi Sulawesi Tengah)”. Jurnal Academica Fisip Untad. Vol.03 No. 01 Pebruari 2011 547-563. 
Rasyid Thalib A, 2006, Wewenang Mahkamah Konstitusi dan Implikasinya dalam Sistem Ketatanegaraan Rebupblik Indonesia, Citra Aditya Bakti, Bandung.

Sugiyono, 2012, Metode Penelitian Administrasi (dilengkapi Metode R\&D), Alfa Beta, Bandung.

Syafrudin dan Ateng.Menuju Penyelenggaraan Pemerintahan Negara yang Bersih dan Bertanggung Jawab”.Jurnal Pro Justisia. Edisi IV Tahun 2000. Bandung: Universitas Parahyanga.

UU No. 23 tahun 2014 Tentag Pemerintah Daerah.

UU No. 5 tahun 1974 Tentang Pemerintah Daerah.

UU No. 22 tahun 1999 Tentang Pemerintahan Daerah

UU No. 23 tahun 2014 Tentag Pemerintah Daerah.

Wasistono, 2009, Pengembangan Organisasi Kecamatan Masa ke Masa. Fokusmedia, Bandung.

Yusdianto. "Hubungan Kewenangan Pusat dan Daerah Dalam Undang-Undang Nomor 23 Tahun 2014 tentang Pemerintahan Daerah”. Jurnal Ilmu Hukum. Vol.2 No. 3, Tahun 2015,(e-ISSN) 483504 dan (ISSN) 24601543.

Zaini Ali. Peranan Kecamatan Dalam Penyelenggaraan Otonomi Daerah. Jurnal administrasi Negara. Vol. III Nomor 2 Oktober 2017.ISSN 1411- 3341. Hal 61-65. 